\title{
Pertumbuhan Arus Kas, Pertumbuhan Laba, Inflasi, Suku Bunga, Nilai Kurs dan Return Saham pada Badan Usaha Milik Negara di Bursa Efek Indonesia
}

\author{
Moh.Abror ${ }^{1}$, Dadang Sadeli ${ }^{2}$ \\ ${ }^{1}$ Universitas Pancasila, Jl. Srengseng Sawah, Jagakarsa, Jakarta Selatan 12640 \\ ${ }^{2}$ Universitas Pendidikan Indonesia, Jl. Dr. Setiabudhi No. 229 Bandung 40381 Jawa Barat
}

\section{N F O A R T I KEL}

\author{
JEL Classification: \\ G14 \\ G30
}

\section{Keywords:}

cashflow growth, earning growth, inflation, interest rates, exchange rates and stock returns state-owned

\section{$A B S T R A C T$}

The study aims to analyze the effect of cashflow growth, earning growth, inflation, interest rates and exchange rates to stock return BUMN. The sample selection is done by using purposive sampling method. Acquired a total sample of 15 companies of 19 state-owned companies listed in Indonesia Stock Exchange during the period 2009 - 2012. This study used multiple linear regression analysis techniques to examine the effect of the independent variable on the dependent variable. Based on the results of the study, there were no variables that deviated of the classical assumption, it indicates that the available data are qualified to use a multiple linear regression model. The results showed that the growth in cash flow, earnings growth, interest rates and exchange rates had no significant effect on stock returns. The study able to show that the interest rate significant positive effect on stock returns.

\begin{abstract}
A B S T RA K
Penelitian bertujuan untuk menganalisis pengaruh pertumbuhan arus kas, pertumbuhan laba, inflasi, suku bunga dan nilai kurs terhadap return saham BUMN. Pemilihan sampel dilakukan dengan menggunakan purposive sampling method. Diperoleh jumlah sampel sebanyak 15 perusahaan dari 19 perusahaan BUMN yang terdaftar di Bursa Efek Indonesia selama periode 2009 - 2012. Penelitian ini menggunakan teknik analisa regresi linear berganda untuk menguji pengaruh variable independen terhadap variable dependen. Berdasarkan hasil penelitian, tidak ditemukan variabel yang menyimpang dari asumsi klasik, hal ini menunjukkan bahwa data yang tersedia telah memenuhi syarat untuk menggunakan model persamaan regresi linier berganda. Hasil penelitian menunjukkan bahwa pertumbuhan arus kas, pertumbuhan laba, suku bunga dan nilai kurs tidak berpengaruh signifikan terhadap return saham. Penelitian berhasil membuktikan bahwa suku bunga berpengaruh positif signifikan terhadap return saham. BUMN.
\end{abstract}




\section{Pendahuluan}

Pasar modal merupakan salah satu center of funding yang produktif bagi pihak yang memiliki kelebihan dana (investor) kepada pihak yang mengalami kekurangan dana (defisit unit/perusahaan). Pasar modal memiliki peranan yang sangat penting dalam kehidupan ekonomi. Keputusan investasi oleh investor (pihak yang memiliki kelebihan dana) ditentukan oleh pengharapan mereka atas kesuksesan suatu usaha di masa yang akan datang. Para investor bersedia menanamkan modalnya jika mereka menganggap prospek suatu investasi menguntungkan.

Investor membutuhkan informasi untuk mengurangi resiko dari ketidakpastian yang mereka hadapi. Informasi tersebut diperlukan untuk mengetahui kondisi emiten, khususnya kondisi keuangan emiten, karena pasar modal dikatakan efisien jika informasi dapat diperoleh dengan mudah dan murah oleh para pemodal, sehingga semua informasi yang relevan dan terpercaya telah tercermin dalam harga-harga saham. Sebelum memutuskan portofolio suatu investasi, investor menganalisis berbagai macam kejadian dan keadaan masa kini dan masa lalu yang diharapkan dapat digunakan untuk memprediksi kejadian yang mungkin terjadi di masa yang akan datang. Respon pasar modal dapat diamati melalui pergerakan harga saham yang terjadi di pasar. Kerangka informasi yang dapat dimanfaatkan oleh investor dipasar secara umum dapat diklasifikasikan menjadi tiga yaitu informasi harga, informasi fundamental perusahaan dan informasi ekonomi makro.

Faktor yang paling dominan mempengaruhi keputusan berinvestasi pada saham perusahan yang listed di Bursa Efek Indonesia adalah faktor fundamental perusahaan dan faktor ekonomi makro. Faktor fundamental perusahaan yang diperhatikan oleh investor adalah pertumbuhan arus kas, pertumbuhan laba.Sedangkan faktor ekonomi makro yang sering menjadi perhatian para investor adalah tingkat inflasi, suku bunga dan nilai kurs. Faktor pertumbuhan arus kas dan pertumbuhan laba perusahaan merupakan gambaran kinerja keuangan sehingga earningsyang diperoleh dan resiko yang dihadapi oleh investor dapat dihindari. Penelitian ini ingin mengungkap sejauh mana perusahaaan BUMN yang terdaftar di Bursa Efek Indonesia mampu memberikan return saham yang optimal kepada investor melalui informasi fundamental perusahaan sebagai dasar keputusan perdagangan sekuritas di pasar modal. Beberapa variabel fundamental perusahaan dalam penelitian ini antara lain pertumbuhan arus kas, pertumbuhan laba, dan faktor makro ekonomi yaituinflasi, suku bunga dan nilai kurs yang akan diamati hubungan kausalitas melalui harga saham terhadap return saham sebagai cerminan nilai keuntungan atau kerugian yang akan diterima para investor.

Return saham merupakan salah satu tujuan utama bagi investor untuk mendapatkan keuntungan yang dinikmati oleh investor atas investasinya, dengan adanya keuntungan yang dapat dinikmati investor akan tertarik untuk melakukan investasi baik jangka pendek maupun jangka panjang di perusahaan yang go public di Bursa Efek Indonesia, termasuk pula perusahaan BUMN Indonesia. Berdasarkan data dari tahun 2009 - 2012, return saham rata-rata perusahaan BUMN yang terdaftar di Bursa Efek Indonesia rata-rata mengalami penurunan yang cukup signifikan bahkan ditahun 2011 mengalami turun drastis samapai minus $-1,19$ kemudian di tahun berikutnya mengalami kenaikan sedikit, atau dengan kata lain penurunan dan kenaikan menjadi fenomena gap, dimana return saham mengalami penurunan dari 65.23 pada tahun 2009 menjadi 47.76 di tahun 2010 (-27\%), di tahun 2011 menurun drastis menjadi sebesar -1,19 (-102\%) dibandingkan dengan tahun 2010. Selanjutnya, return saham rata-rata mengalami kenaikan sangat signifikan di tahun 2012 menjadi 29,71 (+259\%) dibandingkan dengan tahun 2011, tetapi masih dibawah persentase penurunan di tahun 2009 dan 2010.

Besarnya return saham rata-rata dibandingkan dengan rata-rata pertumbuhan arus kas, pertumbuhan laba, inflasi, suku bunga dan nilai kurs untuk perusahaan BUMN yang terdaftar di Bursa Efek Indonesia selama periode tahun 2009-2012 menunjukkan bahwa penurunan atau kenaikan pertumbuhan arus kas, pertumbuhan laba, suku bunga dan nilai kurs perusahaan BUMN yang terdaftar di Bursa Efek Indonesia tidak selalu diikuti dengan penurunan dan kenaikan dengan tingkat yang sama terhadap return saham. Maka dari itu, penulis ingin meneliti seberapa besar pengaruh pertumbuhan arus kas, pertumbuhan laba, suku bunga dan nilai kurs yang merupakan indikator terhadap return saham. Alasan return saham sebagai variabel dependen dikarenakan return saham merupakan tujuan utama investor untuk 
mendapatkan keuntungan atas investasinya.

Menurut Widodo dan Wahyu (2002), yang menguji kandungan informasi arus kas dan laba dalam kondisi good news dan bad news, menyimpulkan bahwa tidak ada hubungan yang signifikan antara return saham dengan semua prediktornya (laporan arus kas dan laba) untuk kategori good news. Sedangkan untuk kategori bad news, informasi arus kas dan laba, secara signifikan tidak berhubungan dengan penurunan return saham di seputar tanggal publikasi laporan keuangan. Penelitian yang dilakukan Pradono (2004), Ismail (2006), serta Kyriazis menunjukkan bahwa laba merupakan faktor yang mempunyai pengaruh terhadap return saham. Hasil penelitian yang berbeda di tunjukkan Mundarytiningsih (2006), menemukan bahwa laba tidak mempunyai pengaruh nyata terhadap return saham. Lebih lanjut Dewanto (2005), menjelaskan bahwa cash flow operation mempunyai hubungan yang positif dengan return saham, tetapi secara statistik pengaruhnya tidak signifikan.

Menurut Zubir (2011),juga menjelaskan bahwa faktor-faktor yang mempengaruhi melencengnya realisasi return suatu investasi terhadap nilai yang di harapakan (expected return), diantaranya sebagai berikut : a) Suku bunga (interest rate)merupakan resiko yang disebabkan oleh perubahan tingkat suku bunga tabungan dan tingkat bunga pinjaman. b) Inflasi (inflation) merupakan menurunnya daya beli masyarakat sebagai akibat dari kenaikan harga barang-barang secara umum. Permintaan terhadap barang-barang meningkat, tetapi daya beli rendah, sehingga masyarakat tidak mampu membelinya, sehingga pada ahirnya perusahaan akan kesulitan dalam memproduksi karna biaya produksi menjadi tinggi dan harga jualnya menjadi tidak terjangkau oleh konsumen. c) Nilai Kurs (exchange rate) merupakan perubahan nilai mata uang, bagi investor yang melakukan investasi di berbagai Negara dengan berbagai mata uang, perubahan kurs menjadi faktor penyebab real return lebih kecil daripada expected return. Perubahan kurs dapat disebabkan oleh perubahan permintaan terhadap mata uang suatu Negara dalam perdagangan internasional dan mata uang sebagai "komoditas" yang diperjual belikan. Lebih lanjut Dewanto (2005), menjelaskan bahwa cash flow operation mempunyai hubungan yang positif dengan return saham, tetapi secara statistik pengaruhnya tidak signifikan.
Berdasarkan uraian dan fenomena diatas serta beberapa penelitian sebelumnya, maka penulis tertarik untuk melakukan penelitian kembali terhadap variabel-variabel yang mempengaruhi Return Saham dan yang menjadi pembeda dengan penelitian terdahulu adalah penelitian ini menganalisis tentang pengaruh variabel pertumbuhan arus kas, pertumbuhan laba, inflasi, suku bunga dan nilai kurs perusahaan dengan obyek perusahaan BUMN yang terdaftar di Bursa Efek Indonesia selama periode tahun 2009-2012. Berdasarkan latar belakang masalah diatas, maka dapat dirumuskan masalah sebagai berikut :

1. Seberapa besar pengaruhpertumbuhan arus kas, pertumbuhan laba, inflasi, suku bunga dan nilai kurs secara simultan terhadap returnsaham BUMN di Bursa Efek Indonesia?

2. Seberapa besar pengaruh pertumbuhan arus kas, pertumbuhan laba, inflasi, suku bunga dan nilai kurs secara parsial terhadap return saham BUMN di Bursa Efek Indonesia?

Adapun tujuan penelitian ini berupaya untuk menjawab rumusan masalah sebagai berikut:

1. Untuk mengetahui, mempelajari dan mengkaji pengaruh pertumbuhan arus kas, pertumbuhan laba, inflasi, suku bungadan nila kurs secara simultan terhadap return saham BUMN di Bursa Efek Indonesia.

2. Untuk mengetahui, mempelajari dan mengkaji pengaruh pertumbuhan arus kas, pertumbuhan laba, inflasi, suku bunga dan nila kurs secara parsial terhadap return saham BUMN di Bursa Efek Indonesia

\section{Telaah Teori dan Pengembangan Hipotesis}

\subsection{Signalling Theory}

Menurut Hartono (2013:392), informasi yang dipublikasikan sebagai suatu pengumuman akan memberikan signal bagi investor dalam pengambilan keputusan investasi. Jika pengumuman tersebut mengandung nilai positif, maka diharapkan pasar akan bereaksi pada waktu pengumuman tersebut diterima oleh pasar. Pada waktu informasi diumumkan dan semua pelaku pasar sudah menerima informasi tersebut, pelaku pasar terlebih dahulu menginterpretasikan dan menganalisis informasi tersebut sebagai signal baik (good news) atau signal buruk (bad news). Jika pengumuman informasi tersebut sebagai 
signal baik bagi investor, maka terjadi perubahan dalam volume perdagangan saham. Signalling Theory dikemukakan dalam ilmu ekonomi dan keuangan untuk memperhitungkan kenyataan bahwa orang dalam perusahaan (insiders) pada umumnya memiliki informasi yang lebih baik dan lebih cepat berkaitan dengan kondisi terkini dan prospek perusahaan dibandingkan dengan investor luar (Subalno 2009).

Disamping itu signalling theory merupakan penjelasan dari asimetri informasi. Asimetri informasi adalah kondisi dimana suatu pihak memiliki informasi yang lebih banyak dari pada pihak lain. Contohnya, pihak manajemen perusahaan memiliki informasi yang lebih banyak dibandingkan dengan pihak investor di pasar modal. Informasi yang diterima tersebut dapat direspons secara berbeda oleh investor. Perusahaan yang memiliki kondisi fundamental yang terpercaya dapat dibedakan dari perusahaan yang memiliki kondisi fundamental yang kurang terpercaya dengan mengirimkan sinyal ke pasar modal. Sinyal dari perusahaan yang kondisi fundamentalnya terpercaya tentu akan direspons oleh investor, sehingga sinyal tersebut menjadi berkualitas. Sedangkan sinyal yang dikirim oleh perusahaan yang kondisi fundamentalnya kurang terpercaya tentu tidak dapat menyamai sinyal yang dikirim oleh perusahaan yang kondisi fundamentalnya terpercaya.

\subsection{Arbitrage Pricing Theory}

Return saham merupakan salah satu faktor yang memotivasi investor berinvestasi dan juga merupakan imbalan atas keberanian investor menanggung risiko atas investasi yang dilakukannya. Pembahasan tentang tingkat keuntungansekuritas dapat dikelompokan dalam dua teori yaitu Capital Asset Pricing Model (CAPM) dan Arbitrage Pricing Theory (APT) oleh (Husnan, 2005). CAPM menggambarkan hubungan tingkat return dan risiko secara sederhana dan hanya menggunakan satu variabel (variabel beta) untuk menggambarkan risiko. Sedangkan APT menggunakan sekian banyak variabel pengukur risiko untuk melihat hubungan return dan risiko.

Menurut Stephen (1999), APT didasarkan pada pemikiran yang menyatakan bahwa 2 kesempatan investasi yang mempunyai karakteristik yang identik tidaklah bisa dijual dengan harga yang berbeda, lebih lanjut teori ini mengasumsikan bahwa tingkat keuntungan tersebut dapat dipengaruhi oleh berbagai faktor dalam perekonomian dan dalam industri. Korelasi diantara tingkat keuntungan dua sekuritas terjadi karena sekuritas-sekuritas tersebut dipengaruhi oleh faktor-faktor yang sama.

\subsection{Return Saham}

Return saham disebut juga sebagai pendapatan saham dan merupakan perubahan nilai harga saham, yang berarti bahwa semakin tinggi perubahan harga saham maka semakin tinggi return yang dihasilkan. Return adalah kuntungan yang dinikmati pemodal atas investasnya. Dengan adanya keuntungan yang dapat dinikmati seorang investor akan tertarik untuk melakukan investasi baik jangka pendek maupun jangka panjang. Menurut Jogiyanto (2013:205), return merupakan hasil yang diperoleh dari investasi dibedakan menjadi dua yaitu: Realized Return, yang merupakan return yang telah terjadi berupa capital gain or capital loss yang dihitung menggunakan data historis dan bersifat sudah terjadi. Kedua, Expected Return merupakan return yang diharapkan akan diperoleh oleh investor di masa yang akan datang yang berupa deviden, yang sifatnya belum terjadi. Investor yang melakukan investasi selalu mengharapkan suatu pengembalian atau yang sering dikenal dengan return. Pada dasarnya return yang diterima dari investasi saham terdiri atas dua jenis, yaitu keuntungan atau kerugian yang terjadi karena kenaikan atau penurunan harga atas asset yang dimiliki, serta pendapatan yang berasal dari komponen yang dinamakan deviden. Return merupakan tingkat pengembalian dari nilai investasi yang diserahkan kepada investor. Sedangkan return saham yang berupa deviden bukanlah hal yang mudah untuk diprediksi karena kebijakan deviden merupakan kebijakan yang sulit bagi manajemen perusahaan return dapat berupa capital gain ataupun deviden untuk investasi pada saham dan pendapatan bunga untuk investasi pada surat hutang. Return menjadi indikator untuk meningkatkan kekayaan para investor, termasuk para pemgang saham. Jogiyanto (2013:206), menjelasakan return saham dapat dihitung dengan rumus sebagai berikut :

$$
\mathrm{Ri}=\begin{aligned}
& \text { Capital Gain or } \\
& \begin{array}{l}
\text { Capital Loss } \\
\text { Pt }-\mathrm{Pt}-1
\end{array} \\
& \mathrm{Pt}-1
\end{aligned}
$$


Keterangan :

Ri :Return Saham,

Pt :Harga saham periode $t$,

Pt-1:Harga saham periode t-1

\subsection{Pertumbuhan Arus Kas}

Laporan arus kas (Statement of Cashflows) adalah laporan yang menyajikan ikhtisar terinci mengenai semua arus kas masuk dan arus kas keluar, atau sumber dan penggunaan kas selama suatu periode tertentu. Informasi tentang arus kas suatu perusahaan berguna bagi para pemakai laporan keuangan sebagai dasar untuk menilai kemampuan perusahaan dalam menghasilkan kas dan setara dengan kas. Tujuan utama laporan arus kas adalah menyediakan informasi yang relevan mengenai penerimaan dan pembayaran kas sebuah perusahaan selama suatu periode. Penyajian laporan aruskas harus diklasifikasikan sesuai dengan aktivitasnya masing-masing sesuai dengan ketentuan SAK No.2 (2012), bahwa Laporan arus kas melaporkan arus kas selama periode tertentu dan diklasifikasikan menurut aktivitas operasi, investasi, dan pendanaan.

Menurut SAK No.2 (2012:2), arus kas adalah arus masuk dan arus keluar kas atau setara kas. Laporan arus kas merupakan revisi dari uang kas diperoleh perusahaan dan bagaimana mereka membelanjakannya. Laporan arus kas merupakan ringkasan dari penerimaan dan pengeluaran kas perusahaan selama periode tertentu. SAK No.2 (2012:3), laporan arus kas harus melaporkan arus kas selama periode tertentu yang di klasifikasikan menurut aktivitas operasi, aktivitas investasi dan aktivitas pendanaan.

\subsection{Pertumbuhan Laba}

Accounting Earnings yang dapat menghasilkan pendapatan saham dan sering digunakan oleh investor untuk menilai kinerja perusahan adalah laba per lembar saham (Earnings Per Share/EPS). Melalui informasi laba bersih per saham investor memperoleh masukan sebagai bahan pertimbangan dalam mengambil keputusan investasi. Oleh karena itu, bersedia atau tidaknya investor untuk berinvestasi (bertransaksi) di pasar modal dipengaruhi oleh informasi Earnings per share tersebut. Dengan demikian dapat disimpulkan bahwa asumsi investor tentang prospek perusahaan di masa yang akan datang dan gambaran investor tentang suatu perusahaan yang diwakili oleh earnings per share akan mempengaruhi harga saham perusahaan tersebut. Oleh karena itu publikasi laporan keuangan yang memuat informasi earnings per share mengakibatkan perubahan harga saham di pasar modal. Informasi earnings per share yang terdapat dalam laporan keuangan diharapkan dapat memberikan informasi bagi investor untuk mengestimasi pendapatan atau return di masa yang akan datang.

Libby et all (1998:15) menjelasakan laba adalah :

"Net income or net earnings (often called profit or the bottom line by nonaccountants) is the excees of total revenues over total expenses. If the total expenses exceed the total revenues, a net loss is reported. (Net losses are normally noted by parentheses around the income figure). When revenues and expenses are equal for the period, the business has operated at breakeven point".

Penelitian yang berkaitan dengan pengaruh antara laba terhadap return telah dilakukan oleh Ball and Brown (1968), yang mengindikasikan adanya hubungan antara laba tahunan dengan return saham. Laporan laba-rugi (Income Statement) atau sering disebut dengan statement of earnings adalah laporan yang mengukur keberhasilan operasi perusahaan selama periode waktu tertentu. Komunitas bisnis dan investasi menggunakan laporan laba-rugi dalam menentukan profitabilitas, nilai investasi dan kelayakan kredit atau kemampuan suatu perusahaan dalam melunasi segala pinjaman perusahaan. Laporan laba rugi dapat membantu para investor untuk memprediksi jumlah, penetapan waktu, dan ketidak pastian dari arus kas masa depan.

\subsection{Inflasi}

Menurut Sukirno (2008), inflasi didefinisikan sebagai suatu proses kenaikan harga-harga yang berlaku dalam suatu perekonomian. Tingkat inflasi berbeda dari satu periode ke periode lain dan berbeda pula dari satu negara ke negara lain. Ada kalanya tingkat inflasi adalah rendah yaitu mencapai dua atau tiga persen. Tingkat inflasi yang moderat mencapai diantara empat sampai sepuluh persen. Inflasi yang sangat serius dapat mencapai tingkat beberapa puluh atau beberapa ratus persen dalam setahun. Kemudian 
menurut Sunariyah (2006), menjelaskan inflasi merupakan kenaikan harga-harga barang dan jasa secara terus-menerus. Dilihat dari segi konsumen, inflasi yang tinggi mengakibatkan daya beli konsumen (masyarakat) menurun. Jika dilihat dari segi perusahaan, inflasi dapat meningkatkan biaya faktor produksi dan menurunkan profitabilitas perusahaan, dan menurut Tandelilin (2010), inflasi merupakan kecenderungan terjadinya peningkatan harga produk-produk secara keseluruhan. Inflasi yang tinggi mengurangi tingkat pendapatan riil yang diperoleh investor dari investasi. Sebaliknya, jika tingkat inflasi suatu negara mengalami penurunan maka hal ini merupakan sinyal yang positif bagi investor seiring dengan turunnya resiko daya beli uang dan resiko penurunan pendapatan riil.

Inflasi yang tinggi mengurangi tingkat pendapatan riil yang diperoleh investor dari investasi. Sebaliknya, jika tingkat inflasi suatu negara mengalami penurunan maka hal ini merupakan sinyal yang positif bagi investor seiring dengan turunnya resiko daya beli uang dan resiko penurunan pendapatan riil. Kenaikan harga dari satu atau dua barang saja tidak dapat disebut inflasi kecuali bila kenaikan itu meluas (atau mengakibatkan kenaikan harga) pada barang lainnya. Sedangkan kebalikan dari inflasi adala deflasi. Indikataor yang sering digunakan untuk mengukur tingkat inflasi adalah Indek Harga Konsumen (IHK). Perubahan IHK dari waktu kewaktu menunjukan pergerakan harga dari paket barang dan jasa yang dikonsumsi mayarakat. Indikator inflasi berdasarkan international best practice antara lain;

1. Indeks Harga Perdagangan Besar (IHPB) Harga Perdagangan Besar dari suatu komoditas harga transaksi yang terjadi antara penjual/pedagang besar pertama dengan pembeli/pedagang besar berikutnya dalam jumlah besar pada pasar pertama atas suatu komoditas.

2. Deflator Produk Domistik Bruto (PDP) menggambarkan pengukuran level harga barang akhir (final goods) dan jasa yang diproduksi di dalam suatu ekonomi. Deflator PDP dihasilkan dengan membagi PDP atas dasar harga nominal dengan PDP atas dasar harga konstan.

\subsection{Suku Bunga}

Suku Bunga adalah surat berharga sebagai pengakuan utang berjangka waktu pendek yang diterbitkan oleh Bank Indonesia dengan sistem diskonto. Suku bunga merupakan salah satu mekanisme yang digunakan Bank Indonesia untuk mengontrol kestabilan nilai rupiah. Dengan menjual suku bunga Bank Indonesia dapat menyerap kelebihan uang primer yang beredar. Suku bunga digunakan sebagai acuan dalam pelaksanaan operasi pengendalian moneter untuk mengarahkan agar rata-rata tertimbang suku bunga satu bulan hasil lelang operasi pasar terbuka berada di sekitar Suku bunga. Selanjutnya suku bunga satu bulan diharapkan mempengaruhi suku bunga pasar uang antar bank dan suku bunga jangka yang lebih panjang. Hasil penelitian Suci (2012), menjelaskan bahwa tingkat suku bunga tidak memiliki pengaruh yang signifikan terhadap IHSG. Hal ini didukung oleh penelitaan oleh Mok et all (2004), yang menemukan bahwa suku bunga tidak berpengaruh secara signifikan terhadap return saham.

\subsection{Nilai Kurs}

Menurut Mirazudin (2008), menjelaskan bahwa kenaikan nilai kurs mata uang dalam negeri disebut apresiasi atas mata uang (mata uang asing lebih murah, hal ini berarti nilai mata uang asing dalam negeri meningkat). Penurunan nilai kurs disebut depresiasi mata uang dalam negeri (mata uang asing menjadi lebihmahal, yang berarti mata uang dalam negeri menjadi merosot). Hubungan antara harga saham dan nilai kurs yang didasarkan pada pendekatan keseimbangan portofolio saham perusahaan. Para investor mengalokasikan kekayaan mereka diantara aset-aset alternatif termasuk uang domestik, sekuritas domestik maupun uang asing.

Dalam kondisi asimetri informasi terhadap harga pasar, perubahan harga pada satu segmen pasar dapat bergantung dari perubahan harga dalam segmen lain melalui SCC. Sehingga, pasar tidak menyerap seluruh informasi secara simultan dan pergerakan harga menunjukkan lead/lag struktur korelasi. Sementara itu Damele et all (2004), menemukan bahwa harga saham bergerak secara cepat mengikuti pergerakan kurs serta mempunyai hubungan yang kuat antara kurs US Dollar terhadap Rupee dengan stock market di India. Dengan menggunakan indek sektoral yang berbeda penelitian tersebut menyimpulkan 
bahwa ketika Rupee terdepresiasi maka stock market terapresiasi begitu pula sebaliknya.

Menurut Granger (1998), secara teoretis perbedaan arah hubungan antara nilai kurs dan harga saham dapat dijelaskan dengan pendekatan tradisional dan model portofolio balance. Pendekatan tradisional mengatakan bahwa hubungan antara nilai kurs dan harga saham adalah positif, di mana perubahan nilai kurs mempengaruhi kompetitifnya suatu perusahaan. Jadi dalam hal ini penulis mencatat implikasi teoretisnya adalah bahwa secara empiris temuan ini semakin memperkuat teori menguatnya kurs mata uang suatu negara memberikan sinyal positif bagi perekonomian suatu Negara tersebut, sehingga secara praktis temuan ini mengimplikasikan bahwa pemerintah harus selalu mengambil langkahlangkah strategis dan selalu mempertahankan untuk memperkuat tingkat nilai kurs mata uangnya agar tidak terdepresiasi terhadap mata uang USD.

\subsection{Tinjauan Penelitian Terdahulu}

Studi empiris yang dilakukan oleh beberapa peneliti terdahulu mengenai beberapa indikator terhadap return saham adalah :

Tabel 1

Tinjauan Penelitian Terdahulu

\begin{tabular}{|c|c|c|c|}
\hline $\begin{array}{l}\text { Nama Peneliti } \\
\text { dan Tahun }\end{array}$ & $\begin{array}{l}\text { Judul } \\
\text { Penelitian }\end{array}$ & $\begin{array}{l}\text { Variabel } \\
\text { dan Metode } \\
\text { Analisis }\end{array}$ & Hasil Penelitian \\
\hline $\begin{array}{l}\text { Biddle, Bowen } \\
\text { dan Wallace, } \\
\text { (1997) }\end{array}$ & $\begin{array}{l}\text { Does EVA } \\
\text { Beat Earnings? } \\
\text { Evidence on } \\
\text { Associations } \\
\text { with stock } \\
\text { return and firm } \\
\text { values }\end{array}$ & $\begin{array}{l}\text { EVA, Residual } \\
\text { Income, Earnigs dan } \\
\text { CFO terhadap return } \\
\text { saham.Dengan metode } \\
\text { Analisis Regresi } \\
\text { Linier }\end{array}$ & $\begin{array}{l}\text { EVA, Residual Income dan CFO } \\
\text { mempunyai hubungan positif dengan } \\
\text { return saham, namun secara statistic } \\
\text { pengaruhnya tidak signifikan terhadap } \\
\text { Stock Return }\end{array}$ \\
\hline $\begin{array}{l}\text { Endang Irianti, } \\
\text { Tjiptowati } \\
(2008)\end{array}$ & $\begin{array}{l}\text { Pengaruh } \\
\text { Kandungan } \\
\text { Informasi Arus } \\
\text { Kas, Komponen } \\
\text { Arus Kas dan } \\
\text { Laba Akuntansi } \\
\text { Terhadap Harga } \\
\text { dan Return } \\
\text { Saham }\end{array}$ & $\begin{array}{l}\text { Arus Kas, Komponen } \\
\text { Arus Kas, Laba } \\
\text { Akuntansi, Harga dan } \\
\text { Return Saham.Dengan } \\
\text { metode Analisis } \\
\text { Regresi Linier dan } \\
\text { Berganda. }\end{array}$ & $\begin{array}{l}\text { Laba Akuntansi, Arus Kas dan } \\
\text { Komponen Arus Kas berpengaruh } \\
\text { signifikan dengan harga saham } \\
\text { dalam model level secara simultan. } \\
\text { Sebaliknya semua variable bebas } \\
\text { tersebut tidak berpengaruh signifikan } \\
\text { dengan return saham dalam model } \\
\text { return, kecuali Arus Kas Operasi } \\
\text { berpengearuh signifikan dengan return } \\
\text { saham. }\end{array}$ \\
\hline
\end{tabular}




\subsection{Kerangka Pemikiran}

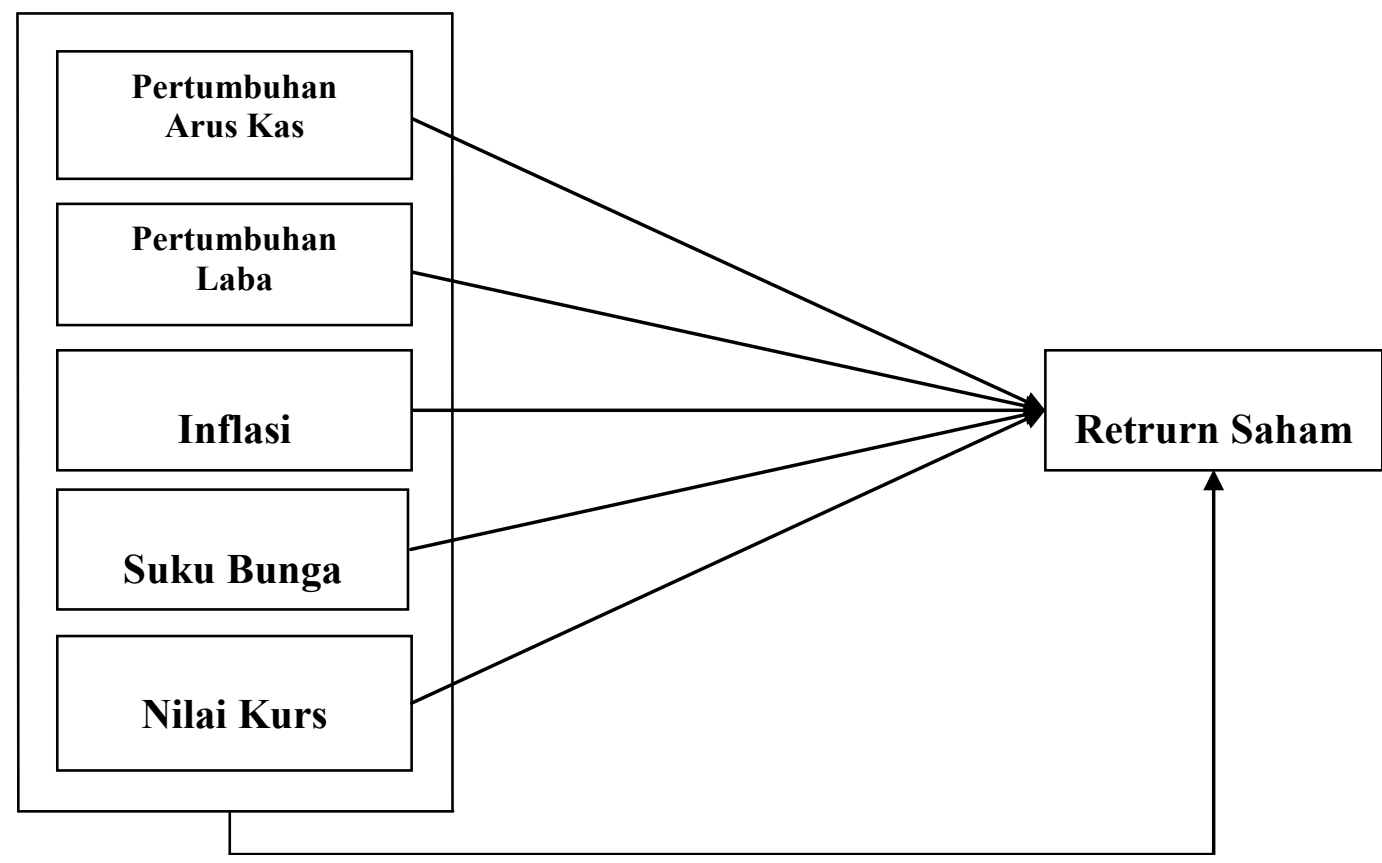

Gambar 1

Kerangka Pikir

\subsection{Hipotesis Penelitian}

Berdasarkan teori dan hasil penelitian empiris yang telah dibahas sebelumnya, hipotesis penelitian sebagai berikut :

H1 : Pertumbuhan arus kas berpengaruh signifikan terhadap return saham

$\mathrm{H} 2$ : Pertumbuhan laba berpengaruh signifikan terhadap return saham

H3 : Inflasi berpengaruh signifikan terhadap return saham.

H4 : Suku bunga berpengaruh signifikan terhadap return saham

H5 : Nilai kurs berpengaruh signifikan terhadap return saham

\section{Metode Penelitian}

Penelitian ini termasuk penelitian kuantitatif. Sugiyono (2012:14), menyatakan bahwa data kuantitatif adalah data yang berbentuk angka atau data kualitatif yang diangkakan. Data kuantitatif dikelompokkan menjadi dua, yaitu:

1. Data diskrit/nominal adalah data yang diperoleh dari hasil menghitung.

2. Data kontinum adalah data yang bervariasi menurut tingkatan dan ini diperoleh dari hasil pengukuran. Data ini dibagi menjadi data ordinal, data interval, dan data ratio.

Sumber data diperoleh secara sekunder. Menurut Sugiyono (2012:129), sumber sekunder merupakan sumber yang tidak langsung memberikan data kepada pengumpul data, misalnya lewat orang lain atau lewat dokumen. Untuk mendapatkan data yang diperlukan dalam penelitian ini, maka teknik pengumpulan data yang digunakan adalah :

1. Riset data melalui website internet, Bursa Efek Indonesia www.idx.co.id, Bank Indonesiawww.bi.co.id, Indonesia Capital Market Directory (ICMD) www.icmd.co.id, dan masing-masing website perusahaan BUMN di Indonesia.

2. Studi Kepustakaan, yaitu teknik pengumpulan data yang dilakukan dengan cara menggali teori-teori dalam buku-buku literatur, majalah, koran dan hasil penelitian sebelumnya berupa jurnal, tesis, disertasi.

Populasi dalam penelitian ini adalah perusahaan BUMN yang terdaftar di Bursa Efek Indonesia (BEI) tahun 2009- 2012. Jumlah populasi sampai dengan tahun 2012 sebanyak 19 perusahaan. Metode pemilihan sampel yang digunakan adalah purposive sampling, yaitu 
penentuan sampel dengan berdasarkan pada kriteria tertentu, Sugiyono (2012:85). Kriteriakriteria yang digunakan dalam penelitian ini adalah :

1. Perusahaan BUMN yang terdaftar di Bursa Efek Indonesia padaperiode penelitiantahun 2009 - 2012 (4 tahun)

2. Menerbitkan laporan keuangan tahunan secara berturut-turut pada periode penelitian tahun 2009-2012.

3. Jika terdapat perusahaan yang sama tetapi memiliki code yang berbeda, misalkan adanya preferred stock, maka hanya satu saja yang diperhitungkan dalam sampel pada periode penelitian tahun 2009-2012.

4. Bukan sebagai outliers atas data secara keseluruhan pada periode penelitian tahun 2009-2012.

5. Semua data yang dibutuhkan tersedia pada periode penelitian tahun 2009-2012.

Data yang digunakan data sekunder yaitu gabungan time series dan cross sectional disebut pooled data, yaitu berupa data keuangan dan harga saham perusahaan serta informasi lainnya, yang diperoleh melalui website resmi di Bursa Efek Indonesia www. idx.co.id,Bank Indonesia www.bi.co.id, Indonesian Capital Market Directori (ICMD) atau www.icmd.co.id, dan masing-masing website perusahaan BUMN yang di teliti serta observasi kepustakaan langsung di Bursa Efek Indonesia. Pengumpulan data menggunakan teknik dokumentasi dengan tipe pooled data. Metode dalam penelitian ini yang digunakan untuk menguji hipotesis dengan menggunakan analisa regresi linear berganda. Persamaan regresi linear berganda digunakan untuk mengetahui elastisitas variabel independen terhadap variabel dependen. Persamaan ini akan digunakan untuk melihat seberapa besar perubahan pada variabel independen yang akan mempengaruhi variabel dependennya, yaitu:

$$
\mathbf{Y}=\alpha+\beta_{1} X_{1}+\beta_{2} X_{2}+\beta_{3} X_{3}+\beta_{4} X_{4}+\beta_{5} \operatorname{Ln} X_{5}+\varepsilon
$$

Keterangan:

Y: Return Saham,

$\mathrm{X} 1$ : Arus Kas,

X2: Pertumbuhan Laba,

$\mathrm{X} 3$ : Inflasi,

X4: Suku Bunga,

LnX5: LnNilai Kurs,

$\varepsilon$ :Epsilon / Variabel kontrol,

$a$ : Konstanta,

\section{$\beta_{n}:$ Koefisien Regresi}

Menurut Gujarati et all (2012), uji koefisien determinasi $(\mathrm{R})$ merupakan sebuah ukuran "Goodness of Fit" untuk melihat seberapa besar proporsi variasi dari variabel independen secara bersama-sama dalam (menjelaskan) mempengaruhi variabel dependen dengan menggunakan rumus sebagai berikut:

$\mathrm{R}^{2}=\frac{\mathrm{JK}_{\mathrm{R}}}{\mathrm{JK}_{\mathrm{Y}}}$

Keterangan :

JK adalah jumlah kuadrat regresi (Explained Sum of Squares)

JK adalah jumlah total kuadrat (Total Sum of Squares)

Dengan keputusan nilai "Cut off" berada antara " $0-1$ ", yang artinya semakin besar nilai $\mathrm{R}$ berarti semakin besar proporsi variasi dari variabel dependen oleh variabel independen. Untuk Pengujian Asumsi Klasik menggunakan uji sebagai berikut :

1. Uji Normalitas

Menurut Ghazali (2006:74), uji normalitas bertujuan untuk menguji apakah dalam model regresi, variabel pengganggu atau residual memiliki distribusi normal. Seperti diketahui bahwa uji $\mathrm{t}$ dan $\mathrm{F}$ mengasumsikan bahwa nilai residual mengikuti ditribusi normal. Kalau asumsi ini dilanggar maka uji statistik menjadi tidak valid untuk jumlah sampel kecil.

2. Uji Multikolinearitas

Menurut Ghazali (2006:57), uji multikolinearitas bertujuan untuk menguji apakah model regresi ditemukan adanya korelasi antar variabel bebas (independen). Jika variabel bebas saling berkorelasi, maka variabel-variabel initidak ortogonal. Variabel ortogonal adalah variabel bebas yang nilai korelasi antar sesama variabel bebas sama dengan nol. Untuk mendeteksi ada atau tidaknya multikolinieritas di dalam model regresi adalah : Melihat angka Collinearity Statistics, yang ditunjukkan oleh nilai VIF (Variance Inflation Factor). Lebih besar dari 10, maka variabel independen yang ada memiliki masalah multikolinieritas. Sebaliknya jika VIF lebih kecil dari 10, maka tidak ditemukan adanya multikolinieritas 
pada variabel independen, Melihat Tolerance pada hasil penilaian multikolinieritas. Jika angka tolerance lebih besar dari 0,10 , maka variabel independen yang ada tidak memiliki masalah multikolinieritas. Sebaliknya jika angka tolerance lebih kecil dari 0,10, maka variabel independen memiliki masalah multikolinieritas.

3. Uji Autokorelasi

Menurut Ghazali (2006:61), Uji autokorelasi bertujuan menguji apakah dalam suatu model regresi linier ada korelasi antara kesalahan pengganggu pada periode $t$ dengan kesalahan pada periode $\mathrm{t}-1$ (sebelumnya). Jika terjadi korelasi, maka dinamakan ada problem autokorelasi. adapun cara yang digunakan oleh penulis untuk mendeteksi ada atau tidaknya yaitu dengan menggunakan uji Durbin-Watson (DW-test), Sehingga untuk pengambilan keputusan ada atau tidaknya autokorelasi dapat dilihat di tabel berikut ini:

Tabel 2

Tabel Uji Autokorelasi

\begin{tabular}{lll}
\hline Hipotesis Nol & Keputusan & Jika \\
\hline $\begin{array}{l}\text { Tidak ada } \\
\text { autokorelasi positif }\end{array}$ & Tolak & $0<\mathrm{DW}<\mathrm{d}_{\mathrm{L}}$ \\
$\begin{array}{l}\text { Tidak ada } \\
\text { autokorelasi positif }\end{array}$ & No decision & $\mathrm{d}_{\mathrm{L}} \leq \mathrm{DW} \leq \mathrm{d}_{\mathrm{u}}$ \\
$\begin{array}{l}\text { Tidak ada } \\
\text { autokorelasi positif }\end{array}$ & Tolak & $4-\mathrm{d}_{\mathrm{L}}<\mathrm{DW}<4$ \\
$\begin{array}{l}\text { Tidak ada } \\
\text { autokorelasi positif }\end{array}$ & No decision & $4-\mathrm{d}_{\mathrm{u}} \leq \mathrm{DW} \leq 4-\mathrm{d}_{\mathrm{L}}$ \\
$\begin{array}{l}\text { Tidak ada } \\
\text { autokorelasi positif } \\
\text { atau negatif }\end{array}$ & Tidak ditolak & $\mathrm{d}_{\mathrm{u}}<\mathrm{DW}<4-\mathrm{d}_{\mathrm{u}}$ \\
\hline
\end{tabular}

Keterangan :

$d_{u}:$ Durbin Watson upper

$d_{L}:$ Durbin Watson lower

4. Uji Heteroskedastisitas

Menurut Ghozali (2006:69), Uji heteroskedastisitas bertujuan menguji apakah dalam model regresi terjadi ketidaksamaan variance dari residual satu pengamatan ke pengamatan yang lainnya. Sehingga suatu model regresi yang baik harus bebas dari masalah heteroskedastisitas. Jika varians dari residual adalah tetap, maka disebut homokedastisitas dan jika berbeda disebut heteroskedastisitas.

\subsection{Pengujian Hipotesis}

1. Uji Koefisien Determinasi $\left(\mathrm{R}^{2}\right)$

Menurut Gujarati et all (2012), uji koefisien determinasi $\left(\mathrm{R}^{2}\right)$ merupakan sebuah ukuran "Goodness of Fit" untuk melihat seberapa besar proporsi variasi dari variabel independen secara bersama-sama dalam menjelaskan (mempengaruhi) variabel dependen. Dengan keputusan nilai "Cut off" berada antara " 0 - 1 ", yang artinya semakin besar nilai $\mathrm{R}$ berarti semakin besar proporsi variasi dari variabel dependen oleh variabel independen.

2. Pengujian Model Penelitian dengan Uji Simultan (Uji F)

Menurut Ghazali (2006:44),Uji F ini berguna untuk membuktikan secara statistik bahwa keseluruhan koefisien regresi signifikan dalam mempengaruhi nilai variabel dependen. Bila nilai parameter regresi $=$ 0 , dapat disimpulkan bahwa tidak terdapat hubungan yang linear antara variabel dependen dengan variabel independen.

Hipotesis untuk uji $\mathrm{F}$ :

$\mathrm{H}_{0}=\beta_{\mathrm{i}}=0$ artinya semua variabel independen yang dihipotesiskan secara simultantidak berpengaruh signifikan terhadap variabel dependen.

$\mathrm{H}_{1}=\beta_{\mathrm{i}} \neq 0$ artinya semua variabel independen yang dihipotesiskan secara simultan berpengaruh signifikan terhadap variabel dependen.

Dengan keputusan yang diperoleh hasil $\mathrm{F}_{\text {hitung }}$ yang dibandingkan dengan $\mathrm{F}_{\text {tabel }}$ dengan level of significant alfa 0,05 dan degree of freedom (df) = n-k-1, maka keputusannya yaitu:

$\mathrm{F}_{\text {hitung }} \leq \mathrm{F}_{\text {tabel }}$ maka $\mathrm{H}_{0}$ Ditolak artinya pertumbuhan arus kas, pertumbuhan laba, inflasi, suku bunga, dan nilai kurssecara simultan tidak berpengaruh signifikan terhadap return saham.

$\mathrm{F}_{\text {hitung. }} \geq \mathrm{F}_{\text {tabel }}$ maka $\mathrm{H}_{1}$

Diterima artinya pertumbuhan arus kas, pertumbuhan laba, inflasi, suku bunga dan nilai kurssecara simultanberpengaruh signifikan terhadap return saham.

3. Uji Parsial (Uji t)

Uji t (t-test) digunakan untuk melihat signifikan pengaruh variabel independen secara parsial terhadap variabel dependen. 
Pada penelitian ini menggunakan uji dua sisi, dengan hipotesis sebagai berkut:

$\mathrm{H}_{0}=\beta_{\mathrm{i}}=0$ artinya variabel independen yang dihipotesiskan tidak berpengaruh signifikan terhadap variabel dependen.

$\mathrm{H}_{1}=\beta_{\mathrm{i}} \neq 0$ artinya variabel independen yang dihipotesiskan berpengaruh signifikan terhadap variabel dependen.

Dari keputusan yang diperoleh hasil $\mathrm{t}_{\text {hitung }}$ yang kemudian dibandingkan dengan $t_{\text {tabel }}$ pada tingkat keyakinan $0,95(\alpha=0,05)$ dan degree of freedom $(\mathrm{df})=\mathrm{n}-\mathrm{k}-1$ maka keputusannya, yaitu:

1. Masing-masing variabel $\mathrm{t}_{\text {hitung }} \leq \mathrm{t}_{\text {tabel }}$ maka $\mathrm{H}_{0}$ ditolak artinya pertumbuhan arus kas, pertumbuhan laba, inflasi, suku bunga dan nilai kurssecara parsial tidak berpengaruh signifikan terhadap return saham.

2. Masing-masing variabel $\mathrm{t}_{\text {hitung }}>\mathrm{t}_{\text {tabel }}$ maka $\mathrm{H}_{1}$ diterima artinya pertumbuhan arus kas,pertumbuhanlaba, inflasi, suku bunga dan nilai kurssecara parsialberpengaruh signifikan terhadap return saham.

\subsection{Definisi Operasionalisasi Variabel}

Menurut Sugiyono (202:39), menjelaskan bahwa variabel dependen adalah variabel yang dipengaruhi atau yang menjadi akibat karena adanya variabel bebas yaitu Return Saham (Y) Jenis return yang digunakan dalam penelitian ini adalah return realisasi atau sering disebut actual return yang merupakan capital gain or capital loss yaitu selisih antara harga saham periode saat ini dengan harga saham pada periode sebelumnya dibagi dengan harga saham periode sebelumnya, yaitu Pt dibandingkian dengan Pt-1 dibagi dengan Pt-1. Sedangkan Menurut Sugiyono (2012:39), variabel independen adalah variabel yang mempengaruhi atau menjadi sebab perubahannya atau timbulnya variabel dependen, yaitu (lima) variabel yang akan diuji pengaruhnya terhadap return saham, yaitu: Pertumbuhan arus kas, pertumbuhan laba, Inflasi, Suku bunga, Nilai kurs.

\section{Hasil Penelitian dan Pembahasan}

Berdasarkan metode purposive sampling sampel pada penelitian ini diperoleh jumlah obyek sampel dari 19 populasi perusahaan BUMN yang terdaftar di Bursa Efek Indonesia periode tahun 2009-2012, yang sesuai dengan kriteria tertentu adalah sebanyak 15 perusahaan BUMNselama periode penelitian tahun 2009- 2012 (4 tahun), maka diperoleh jumlah sampel data penelitian sebanyak 60 data.

Persamaan regresi linear berganda digunakan untuk mengetahui elastisitas variabel independen Pertumbuhan Arus Kas, Pertumbuhan Laba, Inflasi, Suku Bunga, LnNilai Kurs terhadap variabel dependen Return Saham. Persamaan ini digunakan untuk melihat seberapa besar perubahan pada variabel independen tersebut yang akan mempengaruhi variabel dependennya. Berdasarkan olah data dengan program SPSS Vol.19, diperoleh hasil coefficients regresi linear berganda sebagai berikut :

$\mathrm{Y} 1=8656.857+0.172 \mathrm{X} 1+0.083 \mathrm{X} 2-$ 119.699 X3 + 57.075 X4 - 920.671 LnX5 + $\varepsilon$

Dengan penjelasan persamaan sebagai berikut :

1. Konstanta sebesar 8656.857, artinya jika Pertumbuhan Arus Kas, Pertumbuhan Laba, Inflasi, Suku Bunga dan LnNilai Kurs bernilai "0" maka Return Saham bernilai sebesar 8656.857 .

2. Koefisien regresi variabel pertumbuhan arus kas sebesar 0.172 , artinya jika pertumbuhan arus kas mengalami kenaikan 1 satuan, maka return saham akan mengalami kenaikan sebesar 0.172 satuan.

3. Koefisien regresi variabel pertumbuhan laba sebesar 0.083 , artinya jika pertumbuhan laba mengalami kenaikan 1 satuan, maka return saham akan mengalami kenaikan sebesar 0.083 satuan.

4. Koefisien regresi variabel inflasi sebesar -119.699, artinya jika inflasi mengalami penurunan 1 satuan, maka return saham akan mengalami penurunan sebesar 199.699 satuan.

5. Koefisien regresi variabel suku bunga sebesar 57.075, artinya jika suku bunga mengalami kenaikan 1 satuan, maka return saham akan mengalami kenaikan sebesar 57.075 satuan.

6. Koefisien regresi variabel LnNilai Kurs sebesar -920.671, artinya jika LnNilai Kurs mengalami penurunan 1 satuan, maka return saham akan mengalami penurunan sebesar 920.671 satuan.

Hasil pengujian hipotesis seperti tampak pada tabel berikut. 
Tabel 3

Hasil Pengujian hipotesis

\begin{tabular}{|c|c|c|c|c|c|c|c|c|}
\hline & \multirow{2}{*}{ Model } & \multirow{2}{*}{$\begin{array}{l}\text { Jnstandardized } \\
\text { Coefficients B }\end{array}$} & \multirow{2}{*}{ Std. Error } & \multirow{2}{*}{$\begin{array}{c}\text { Standardized } \\
\text { Coefficients Beta }\end{array}$} & \multirow{2}{*}{$\mathbf{t}$} & \multirow{2}{*}{ Sig. } & \multicolumn{2}{|c|}{$\begin{array}{l}\text { Collienarity } \\
\text { Statistics }\end{array}$} \\
\hline & & & & & & & Tolerance & VIF \\
\hline \multirow[t]{6}{*}{1} & (Constant) & 8656.857 & 4887.946 & & 1.771 & .082 & & \\
\hline & X1 PERTUMBUHAN ARUS KAS & .172 & .113 & .176 & 1.531 & .132 & .931 & 1.074 \\
\hline & X2 PERTUMBUHAN LABA & .083 & .045 & .216 & 1.860 & .068 & .918 & 1.090 \\
\hline & X3 INFLASI & -119.699 & 42.327 & -1.103 & -2.828 & .007 & .481 & 2.310 \\
\hline & X4 SUKU BUNGA & 57.075 & 14.953 & .630 & 3.817 & .000 & .454 & 2.205 \\
\hline & X5 Ln NILAI KURS & -920.671 & 519.145 & -.606 & -1.773 & .082 & .106 & 9.439 \\
\hline
\end{tabular}

a. Dependent Variable : Y1 RETURN SAHAM

Uji t (t-test) digunakan untuk melihat signifikansi pengaruh variabel independen secara individu terhadap variabel dependen, dengan menggunakan uji dua sisi yang diperoleh hasil $\mathrm{t}_{\text {hitung }}$ (pada taraf signifikansi alfa $(\alpha)=0.05$ $: 2=0.025$ (uji 2 sisi) dan derajat bebas $\mathrm{db}=\mathrm{n}$ $\mathrm{k}-1$, atau $\mathrm{db}=60-5-1=54$, maka diperoleh nilai $\mathrm{t}_{\text {tabel }}=2.005$.

Dari hasil $t_{\text {hitung }}$ tersebut dapat diambil kesimpulan bahwa :

1. $\mathrm{H} 2$ : pertumbuhan arus kas tidak berpengaruh signifikan terhadap return saham, hal ini dibuktikan bahwa $\mathrm{t}_{\text {hitung }}<\mathrm{t}_{\text {tabel }}(1.531<2.005)$. Maka $\mathrm{H}_{0}$ Ditolak, bahwa pertumbuhan arus kas tidak berpengaruh signifikan terhadap return saham.

2. H3 : pertumbuhan laba tidak berpengaruh signifikan terhadap return saham, hal ini dibuktikan bahwa $\mathrm{t}_{\text {hitung }}<\mathrm{t}_{\text {tabel }}(1.860<2.005)$. Maka $\mathrm{H}_{0}$ Ditolak, bahwa pertumbuhan laba tidak berpengaruh signifikan terhadap return saham.

3. H4 : inflasi tidak berpengaruh signifikan terhadap return saham, hal ini dibuktikan bahwa $\mathrm{t}_{\text {hitung }}<\mathrm{t}_{\text {tabel }}(-2.828<2.005)$. Maka $\mathrm{H}_{0}$ Ditolak, bahwa inflasi tidak berpengaruh signifikan dan negatif terhadap return saham.

4. H5 : suku bunga berpengaruh signifikan terhadap return saham, hal ini dibuktikan bahwa $\mathrm{t}_{\text {hitung }}>\mathrm{t}_{\text {tabel }}(3.817>2.005)$. Maka $\mathrm{H}_{5}$ Diterima, bahwa suku bunga berpengaruh signifikan dan positif terhadap return saham.

5. H6 : Ln-nilai kurs tidak berpengaruh signifikan terhadap variabel return saham, hal ini dibuktikan bahwa $\mathrm{t}_{\text {hitung }}<\mathrm{t}_{\text {tabel }}(-1.773$ $<$ 2.005). Maka $\mathrm{H}_{0}$ Ditolak, bahwa Ln- nilai kurs tidak berpengaruh signifikan dan negatif terhadap return saham.

Hipotesis $\mathrm{H}_{1}$ disebutkan bahwa pertumbuhan arus kas, pertumbuhan laba, inflasi, suku bunga dan Ln nilai kurs secara simultan berpengaruh signifikan terhadap return saham. Berdasarkan hasil uji $\mathrm{F}$ dapat di ambil kesimpulan bahwa hipotesis $\mathrm{H}_{1}$ yang menyatakan bahwa semua variabel pertumbuhan arus kas, pertumbuhan laba, inflasi, suku bunga dan Ln nilai kurs secara simultan berpengaruh signifikan terhadap variabel return saham diterima. Artinya bahwa, pertumbuhan arus kas, pertumbuhan laba, inflasi, suku bunga dan Ln nilai kurs secara simultan berpengaruhdan signifikan terhadap return saham. Hasil penelitian ini menunjukkan bahwa faktor fundamental perusahaan yang berasal dari laporan keuangan yang di representasikan oleh pertumbuhan arus kas dan pertumbuhan laba serta faktor makro ekonomi (inflasi, suku bunga dan LnNilai kurs) secara bersama-sama memberikan sinyal yang positif bagi investor untuk memprediksi kinerja perusahaan dalam hal ini kinerja keuangan perusahaan di masa mendatang sehingga menjadi pertimbangan investor untuk memilih portofolio saham suatu perusahaan dengan tujuan untuk memperoleh keuntungan atas asset yang di investasikan.

Hipotesis $\mathrm{H}_{2}$ disebutkan bahwa pertumbuhan arus kas tidak berpengaruh signifikan terhadap return saham. Berdasarkan hasil uji $\mathrm{t}$ yang dilakukan, hipotesis $\mathrm{H}_{0}$ menyatakan bahwa pertumbuhan arus kas tidak berpengaruh signifikan terhadap return saham ditolak. Artinya, pertumbuhan arus kas tidak 
berpengaruh signifikan terhadap return saham. Semakin baik pertumbuhan arus kas suatu perusahaan menunjukkan bahwa perusahaan mampu menjalankan kegiatan operasinya untuk menghasilkan keuntungan atau laba. Arus kas merupakan salah satu informasi yang penting dan menjadi daya tarik bagi investor untuk menanamkan asetnya (modal), termasuk untuk membayar hutang-hutangnya.

Hipotesis $\mathrm{H}_{3}$ disebutkan bahwa pertumbuhan laba tidak berpengaruh signifikan terhadap return saham. Berdasarkan hasil uji $\mathrm{t}$ yang dilakukan, hipotesis $\mathrm{H}_{0}$ menyatakan bahwa pertumbuhan laba tidak berpengaruh signifikan terhadap return saham ditolak. Artinya, pertumbuhan laba tidak berpengaruh signifikan terhadap return saham. Statement of earnings adalah laporan yang mengukur kinerja keberhasilan operasi perusahaan selama periode waktu tertentu. Komunitas bisnis dan investasi menggunakan statement of earnings dalam menentukan profitabilitas, nilai investasi dan kelayakan kredit atau kemampuan suatu perusahaan dalam melunasi segala pinjaman perusahaan. Statement of earnings dapat membantu para investor untuk memprediksi jumlah, penetapan waktu, dan ketidak pastian keuntungan di masa depan. Statement of earnings berguna sebagai alat untuk mengevaluasi kinerja masa lalu perusahaan, dan memberikan dasar untuk memprediksikan kinerja keuangan masa depan, dalam hal ini adalah perolehan laba perusahaan yang optimal. Hipotesis $\mathrm{H}_{4}$ disebutkan bahwa inflasi tidak berpengaruh signifikan terhadap return saham. Berdasarkan hasil uji t yang dilakukan, hipotesis $\mathrm{H}_{0}$ menyatakan bahwa inflasi tidak berpengaruh signifikan dan negatif terhadap return saham ditolak. Artinya, bahwa inflasi tidak berpengaruh signifikan dan negatifterhadap return saham. Inflasi merupakan kecenderungan terjadinya peningkatan harga produk-produk secara keseluruhan. Inflasi yang tinggi mengurangi tingkat pendapatan riil yang diperoleh investor dari investasi. Sebaliknya, jika tingkat inflasi suatu negara mengalami penurunan maka hal ini merupakan sinyal yang positif bagi investor seiring dengan turunnya resiko daya beli uang dan resiko penurunan pendapatan riil.

Hipotesis $\mathrm{H}_{5}$ disebutkan bahwa suku bunga berpengaruh signifikan terhadap return saham. Berdasarkan hasil uji t, hipotesis $\mathrm{H}_{5}$ menyatakan bahwa suku bunga berpengaruh seignifikan dan positif terhadap return saham diterima. Artinya, bahwa suku bunga berpengaruh signifikan dan positif terhadap return saham. Penelitian oleh Kewal (2012) menjelaskan bahwa tingkat suku bunga tidak berpengaruh signifikan terhadap indek harga saham gabungan.

Hipotesis $\mathrm{H}_{6}$ disebutkan bahwa LnNilai Kurs tidak berpengaruh signifikan terhadap return saham. Berdasarkan hasil uji $\mathrm{t}$ yang dilakukan, hipotesis H0 menyatakan bahwa LnNilai Kurs tidak berpengaruh signifikan dan negatif terhadap return saham ditolak. Para investor mengalokasikan kekayaan mereka diantara aset-aset alternatif termasuk uang domestik, sekuritasdomestikmaupunuangasing. Peran nilai kurs adalah untuk menyeimbangkan antara pemenuhan (supply) dan kebutuhan (demand) aset yang ada. Oleh karena itu setiap perubahan kebutuhan dan pemenuhan dari aset akan mengubah keseimbangan nilai kurs. Jadi kesimpulanya bahwa LnNilai Kurs tidak berpengaruh dan negatif terhadap return saham,hal ini dikarenakan dalam periode penelitian Nilai Kurs relatif stabil sehingga perubahan nilai kurs terhadap harga saham dan return saham perusahaan BUMN yang terdaftar di Bursa Efek Indonesia tidak terpengaruh oleh perubahan nilai kurs (ID Rupiah terhadap US Dollar), sehingga harga saham relatif stabil dan termasuk saham yang defensive yaitu saham yang cenderung lebih stabil dalam masa resesi atau situasi perekonomian yang tidak menentu.

Hasil penelitian ini berbeda dengan penelitian oleh Kewal (2012), menyatakan nilai kurs berpengaruh negatif dan signifikan terhadap indek harga saham gabungan, dan berbeda pula dengan penelitian oleh Wongbangpo dan Sharma (2002) menyatakan bahwa nilai kurs memiliki hubungan positif terhadap harga saham di Negara Indonesia, Malaysia dan Filipina, serta penelitian oleh Kendir (2008) menjelasakan bahwa nilai kurs berpengaruh secara positif terhadap return dari semua portofolio saham yang ada.

\section{Simpulan, Keterbatasan dan Implikasi Hasil Penelitian}

Hasil pengujian hipotesis dengan menggunakan analisis regresi linear berganda dengan lima variabel independen pertumbuhan arus kas, pertumbuhan laba, inflasi, suku bunga dan nilai kurs serta satu variabel dependen 
return saham, menyatakan sebagai berikut :

1. Bahwa pertumbuhan arus kas, pertumbuhan laba, inflasi, suku bunga dan nilai kurssecara simultanberpengaruh signifikan terhadap return saham perusahaan BUMN yang terdaftar di Bursa Efek Indonesia selama periode penelitian tahun 2009-2012. Hal ini berarti bahwa faktor fundamental perusahaan yang berasal dari laporan keuangan yang di representasikan oleh pertumbuhan arus kas dan pertumbuhan laba serta faktor makro ekonomi (inflasi, suku bunga dan LnNilai kurs) secara bersama-sama memberikan sinyal yang positif bagi investor untuk memprediksi kinerja perusahaan dalam hal ini kinerja keuangan perusahaan di masa mendatang sehingga menjadi pertimbangan investor untuk memilih portofolio saham suatu perusahaan dengan tujuan untuk memperoleh keuntungan atas asset yang di investasikan. Semakin baik kinerja keuangan perusahaan, investor semakin merespon dengan baik untuk menanamkan asetnya dalam perusahaan.

2. Pertumbuhan Arus Kas tidak berpengaruh signifikan terhadap return saham, hal ini dikarenakan bahwa investor tidak menjadikan faktor pertumbuhan arus kas sebagai faktor yang mempengaruhi minat investor untuk menentukan pemilihan saham pada periode penelitian. Pertumbuhan arus kas yang tinggi atau rendah belum tentu menjadi pertimbangan investor untuk memilih saham suatu perusahaan, sehingga return saham ditentukan oleh faktor di luar pertumbuhan arus kas, misalnya faktor pertumbuhan laba dan lain-lain.

3. Pertumbuhan Laba tidak berpengaruh signifikan terhadap return saham, hal ini dikarenakan bahwa investor tidak menjadikan faktor pertumbuhan laba sebagai faktor yang mempengaruhi minat investor untuk menentukan pemilihan saham pada periode penelitian. Pertumbuhan laba yang tinggi atau rendah belum tentu menjadi pertimbangan investor untuk memilih saham suatu perusahaan, sehingga return saham ditentukan oleh faktor di luar pertumbuhan laba dan faktor lain yang tidak dalam model penelitian ini.

4. Inflasi tidak berpengaruh signifikan dan negatif terhadap return saham, hal ini dikarenakan bahwa investor tidak menjadikan faktor inflasi sebagai respon negatif yang mempengaruhi minat investor untuk menentukan pemilihan saham pada periode penelitian. Inflasi yang tinggi ataupun rendah belum tentu menjadi pertimbangan investor untuk berinvestasi, tetapi ternyata return saham BUMN yang terdaftar di Bursa Efek Indonesia merupakan saham yang secara fundamental maupun teknikal sangat baik dan termasuk saham yang defensive yang cenderung lebih stabil dalam masa resesi atau situasi perekonomian yang tidak menentu.

5. Suku Bunga berpengaruh signifikan dan positif terhadap return saham, hal ini dikarenakan bahwa selama periode penelitian terjadi karena tingkat suku bunga cenderung menurun sehingga di respon positif oleh investor dalam menanamkan asetnya (modal) untuk berinvestasi di perusahaan BUMN di Bursa Efek Indonesia dengan tujuan untuk mendapatkan keuntungan atau return saham.

6. Nilai Kurs tidak berpengaruh dan negatif terhadap return saham, hal ini dikarenakan dalam periode penelitian Nilai Kurs relatif stabil sehingga perubahan nilai kurs terhadap harga saham dan return saham perusahaan BUMN yang terdaftar di Bursa Efek Indonesia tidak terpengaruh oleh perubahan nilai kurs (ID Rupiah terhadap US Dollar), sehingga harga saham relatif stabil dan termasuk saham yang defensive yaitu saham yang cenderung lebih stabil dalam masa resesi atau situasi perekonomian yang tidak menentu.

Dalam penelitian ini penulis menyampaikan bahwa terdapat beberapa keterbatasn, terutama pada hal-hal sebagai berikut :

1. Hasil penelitian ini menyatakan bahwa proporsi variasi variabel dependenyang dapat dijelaskan (dipengaruhi) oleh variabel independensebesar $69.20 \%$ dan sisanya sebesar $30.80 \%$ di pengaruhi oleh faktorfaktor lain, sehingga masih banyak variabel lain yang berpengaruh terhadap return saham namun tidak masuk dalam model penelitian ini.

2. Penelitian ini terbatas pada saham portofolio yang di miliki oleh BUMN yang terdaftar di Bursa Efek Indonesia sehingga masih banyak perusahaan emiten lainnya yang tidak masuk dalam penelitian ini.

3. Penelitian ini hanya mencakup pada periode 
penelitian selama 4 tahun yaitu tahun 2009 - 2012 saja, sehingga data penelitian yang diperoleh masih dalam waktu terbatas dan belum dapat digeneralisasi untuk periode yang lebih panjang.

4. Penelitian ini tidak membedakan jenis industri BUMN yang terdaftar di Bursa Efek Indonesia, sehingga penelitian ini tidak dapat di bandingkan dengan masing-masing industri sejenis.

Saran-saran yang dapat penulis kemukakan setelah melakukan penelitian ini adalah sebagai berikut :

1. Bagi emiten, peningkatan return saham dapat meningkatkan kepercayaan publik (investor) terhadap emiten. Hal ini sangatlah penting, karena pada saat emiten memerlukan sumber pendanaan baru maka para investor akan merespon positif dan segera menanamkan modalnya, dengan cara menunjukkan kinerja saham yang baik dan memiliki ketahanan terhadap faktor makro ekonomi yang baik pula agar dapat menghasilkan keuntungan yang optimal.

2. Bagi investor, dalam menganalisis kinerja saham emiten, informasi mengenai pertumbuhan arus kas, pertumbuhan laba, inflasi, suku bunga dan nilai kurs sangat layak untuk dicermati. Hal ini mengingat bahwa kelima variabel indikator tersebut secara simultan berpengaruh dan signifikan terhadap return saham. Oleh karena itu investor sebaiknya selalu mengikuti perkembangan harga saham sebelum dan sesudah publikasi laporan keuangan (pertumbuhan arus kas dan pertumbuhan laba) dan faktor makro ekonomi (inflasi, suku bunga dan nilai kurs), sehingga investor dapat mengukur return saham secara tepat sebelum mengambil keputusan untuk membeli ataupun menjualnya.

3. Bagi kalangan akademisi yang berminat untuk melakukan penelitian selanjutnya mengenai return saham, disarankan :

a. Masih terdapat $30.80 \%$ faktor lain yang belum masuk dalam model penelitian ini sehingga diharapkan bagi peneliti selanjutnya untuk menggali faktor lain secara komprehensif, karena sangat dimungkinkan variabel lain dapat menjelaskan (berpengaruh) terhadap return saham.

b. Menambah rentang waktu yang lebih panjang sehingga penelitian berikutnya diharapkan mendapatkan hasil yang lebih baik dan dapat digeneralisasikan dalam penelitian sejenis, serta menghasilkan penelitian yang lebih baik.

\section{Daftar Pustaka}

Biddle, Bowen, Wallace, 1997, Does EVA Beat Earnings? Evidence om Associations with Return Stock and Firm Value, Journal of Accounting and Economics 24, Page 301336.

Ball Ray, Phillip Brown, 1968, An Empirical Evaluation of Accounting Income Numbers, Journal of Accounting Research, Autum

Bank Central Republik Indonesia, Rate Suku Bunga, Inflasi dan Kurs Uang (Kurs), Bank Indonesia, www.bi.co.id

Bursa Efek Indonesia, Laporan Keuangan BUMN dan Harga Saham BUMN, www. idx.co.id

Dewanto H, 2005, Analisis Pengaruh Economic Value Added, Market Value Added, Residual Income dan Cash flow Operation Terhadap Imbal Hasil Saham Sektor Pertambangan di BEJ 1995-2004. Universitas Indonesia.

Dornbusch R, Fischer, S., and Richard Star, 2008, Makro Ekonomi. Terjemahan, oleh : Roy Indra Mirazudin, SE. Jakarta : PT Media Global Edukasi.

Ghozali, Imam, 2006, Aplikasi Analisis Multivariate Dengan SPSS, Universitas Diponegoro, Semarang

Granger C.W., Huang B, Yang C, 1998, A Bivariate Causality Between Stock Prices And Exchange Rates: Evidence from Recent Asian Flu. The Quarterly Review Of Economics And Finance.Volume 40:337 $\square 354$

Gujarati, Damodar N, Porter, Dawn C, 2012, Basic Econometrics (Dasar-Dasar Ekonometrik), 5th Edition, McGraw-Hill, Salemba Empat, Jakarta

Indosia Capital Market Directory (ICMD), Summary of Financial Statement, www. icmd.co.id

Hartono, Jogiyanto, 2013, Teori Portofolio dan Analisis Investasi Edisi ke 7, BPFE, Yogyakarta.

Husnan S., 2005, Dasar-dasar Teori Portfolio dan Analisis Sekuritas, UPP AMP.YKPN

Ikatan Akunatan Indonesia, 2012, Standar Akuntansi Keuangan, Edisi ke 1, Jakarta.

Ismail, A, 2006, Is EVA more Associated with 
Stock Return than Accounting Earnigs, The UK Evidence. International Journal of Mangerial Finance, Vol.2 (4) Page 343-353.

Kandir, Serkan Yilmaz, 2008, Macroeconomic Variables, Firm Characteristics and Stock Returns: Evidence from Turkey. International Research Journal of Finance andEconomics ISSN 1450-2887 Issue 16

Robert Libby, Patricia Libby, Daniel G. Short, 1998, Financial Accounting, 2nd Edition, International Editions by the Mc Grew Hill Companies, Printed in USA.

Mundaryatiningsih S, 2006, Analisis Pengaruh Kinerja Keuangan Perusahaan Terhadap Kapitalisasi Pasar dan Return Saham Perusahaan Publik di BEJ, Tesis, Institut Teknologi Bandung.

Pradono, 2004, Pengaruh Economic Value Added, Residual Income, Earnings dan Arus Kas Operasi Terhadap Return Saham yang diterima oleh Pemegang Saham, Studi Empiris Perusahaan Manufaktur di BEJ, Tesis, Universitas Erlangga, Surabaya

Subalno, 2009 Analisis Pengaruh Faktor Fundamental dan Kondisi Ekonomi Terhadap Return Saham, Tesis Universitas Diponogoro, Semarang

Suci K, Suramaya, 2012, Pengaruh Inflasi, Suku Bunga, Kurs, dan Pertumbuhan PDP Terhadap Indek Harga Saham Gabungan, Jurnal Ekonomi, Volume 8, Nomor 1:62.

Sugiyono, 2012, Metode Penelitian Kuantitaif, Kualitatif dan R \& D, Alfabeta, Bandung.

Sukirno, Sadono, 2008, Teori Pengantar Mikroekonomi, Edisi ke 3, Rajawali Pers, Jakarta.

Sunariyah, 2006, Pengetahuan Pasar Modal, Edisi ke 5, UPP STIM YKPN, Yogyakarta.

Stephen A. Ross, Randolph W. Westerfield, Jeffrey Jaffe, 1999, Corporate Finance, 4th Edition, International Editions by Mc Grew Hill Companies, Printed in Singapore

Tandelilin, Eduardus, 2010, Portofolio dan Investasi Teori dan Aplikasi, Edisi ke 1, Kanisius, Yogyakarta.

Tjiptowati I., Endang, 2008, Pengaruh Kandunagan Informasi Arus Kas, Komponen Arus Kas dan Laba Akuntansi, Tesis, Universitas Diponogoro, Semarang

Widodo, Wahyu, 2002, Pengaruh Informasi Kas Terhadap Harga Saham Perusahaan LQ45 di BEJ, Tesis, Universitas Diponogoro, Semarang.

Wongbangpo, Praphan, Subhash C. Sharma,
2002, Stock Market and Macroeconomic Fundamental Dynamic Interaction, ASEAN-5 Countries. Journal of Asian Economics 13:27-51.

Zubir, Zalmi, 2011, Manajemen Portofolio Penerapan Dalam Investasi Saham Salemba Empat, Jakarta 